Article

\title{
Patent Analysis of High Efficiency Tunneling Oxide Passivated Contact Solar Cells
}

\author{
Chieh-Wa Tsai ${ }^{1,2}{ }^{\mathbb{D}}$, Tung-Kuan Liu ${ }^{1}{ }^{\mathbb{D}}$ and Po-Wen Hsueh ${ }^{1, *}$ \\ 1 College of Engineering, National Kaohsiung University of Science and Technology, No.1, University Rd., \\ Kaohsiung 824, Taiwan; 0515914@nkust.edu.tw (C.-W.T.); tkliu@nkust.edu.tw (T.-K.L.) \\ 2 Metal Industries Research \& Development Centre, No.1001, Kaonan Highway, Kaohsiung 811, Taiwan \\ * Correspondence: hpowen@nkust.edu.tw; Tel.: +886-7-601-1000 (ext. 32212)
}

Received: 18 April 2020; Accepted: 10 June 2020; Published: 12 June 2020

\begin{abstract}
High efficiency tunneling oxide passivated contact (TOPCon) solar cell is the traditional PN junction structure, combined the advantages of using a thin film of the passivated silicon surface to separate the metal from the silicon wafer. In this study, the patent analysis of high efficiency TOPCon solar cell is presented. The structure and process technology of TOPCon solar cell were analyzed first, which is used as the basis for the key words of the patent search. The patent management chart analysis is provided, and then the patent portfolio of the main research countries and important manufacturers on the research subject can be recognized. Moreover, the technology-function matrix analysis is used to comprehend the technical development trend of the research topic. The results indicate the TOPCon solar cell technology currently entered into the maturity stage in 2019, and the companies with the top three number of patents are LG Electronics, SunPower, and SolarCity (which was acquired by Tesla in 2016). SunPowern is the earliest patent assignee, and LG Electronics is the follower, while its patent outputs are heavily concentrated after 2014. Patent technology-function matrix found the development focus of the device-related technologies are tunneling oxide and polycrystalline silicon, with a total of 21 patents, and the development focus of process-related technologies are the process of tunneling oxide layers and the process of polysilicon film. Based on the analysis results, the future development prospects of the research topic and the direction of patent portfolio are evaluated.
\end{abstract}

Keywords: patent analysis; TOPCon; solar cells; patent portfolio

\section{Introduction}

In the past half century, the use of large amounts of petroleum fuel in response to their economic benefits has caused a rapid increase in the concentration of greenhouse gases, such as carbon dioxide in the atmosphere. Global warming, rising sea levels and increasing global climate change are increasingly evident. This phenomenon has caused a huge negative impact on water resources, crops, natural ecosystems and human health. Therefore, the global warming and the energy crisis has become an urgent problem to be solved, so the development of the various renewable energy technologies has become an important issue in the current industry [1].

Figure 1 shows the global energy supply forecast. As shown, nearly $50 \%$ of the global energy supply will come from renewable energy by 2050. Figure 2 illustrates the global power production source forecasts. More than $85 \%$ of global electricity is generated by the renewable energy, where the solar power including solar photovoltaic (PV) and solar thermal accounts for up to $40 \%[2,3]$. 


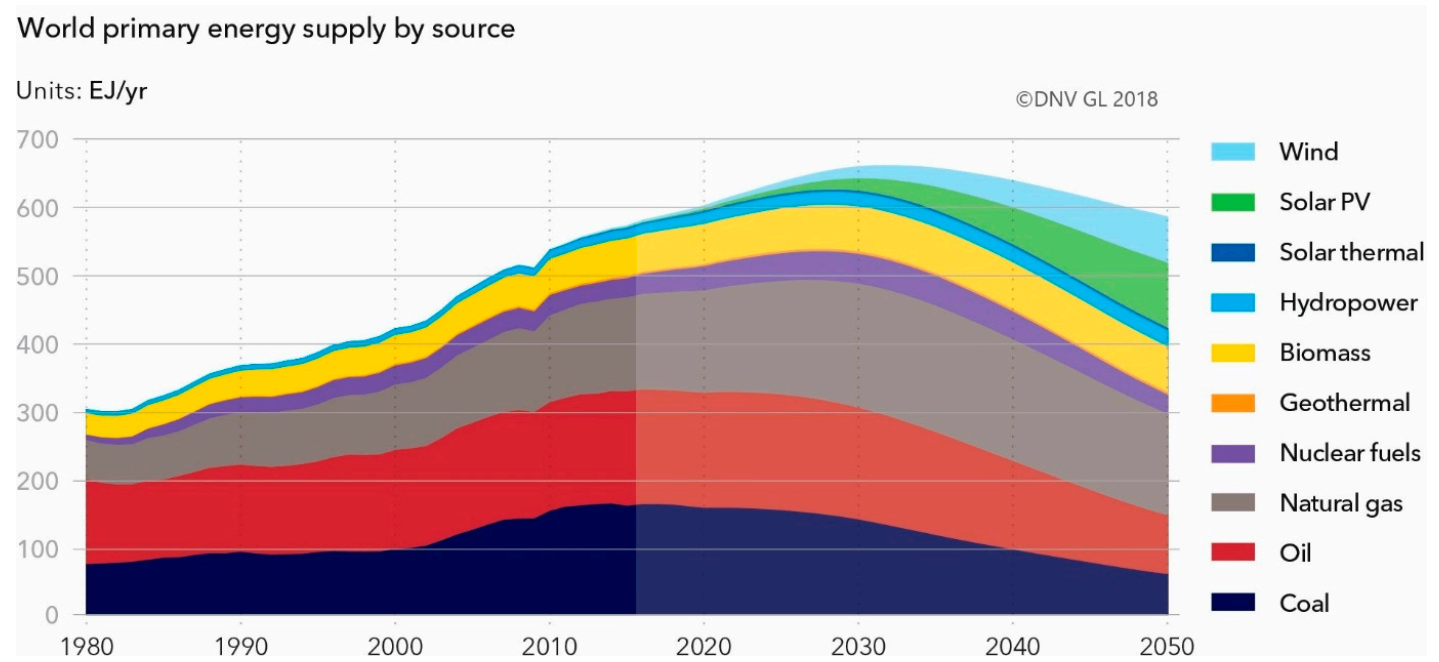

Figure 1. Global energy supply forecast [1].

World electricity generation by power station type

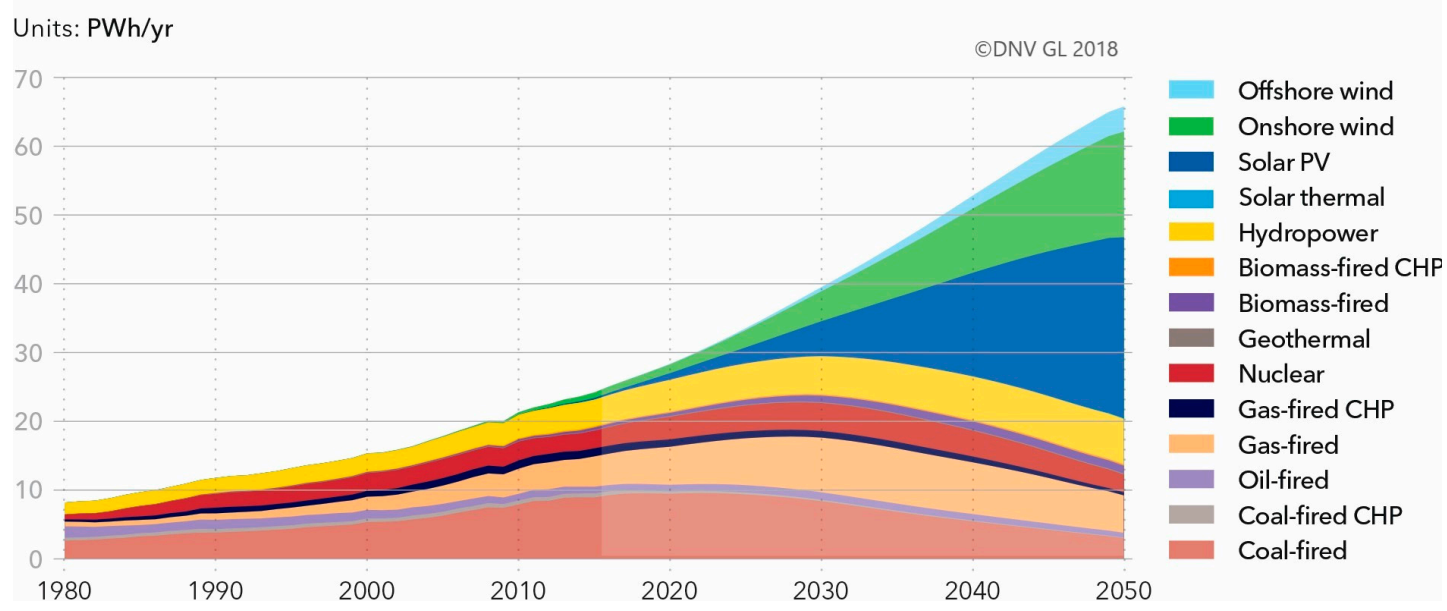

Figure 2. Global power production source forecast [1].

Table 1 presents the conversion efficiencies of various types of solar cells and the price per watt. However, due to the current active attitudes of research and development for next generation high efficiency solar cells in the world, the data in the table will be updated rapidly within a few years [4-9].

In the next 10 to 20 years, it is expected that the crystalline silicon wafer solar cells should remain the mainstream of the PV market. However, the solar industry has almost entirely shifted away from the polycrystalline industry of conventional Al back surface field (Al-BSF) solar cell. Even passivated emitter and rear cell (PERC) based solar cells more from polycrystalline type to monocrystalline type. While passivated emitter rear totally diffused (PERT) solar cells, unlike standard solar cells and PERC, which both use an aluminum-alloy BSF, have a diffused rear surface. By 2025, high-efficiency solar cells using n-type substrate will become the mainstream products in the market. Although organic-inorganic halide perovskites have recently been developed as a new class of light absorbers with high efficiency, used for tandem solar applications, the development of the perovskite tandem solar cell is still in progress at the level of lab research, and will not be commercialized soon, as it is costly to replace the silicon based solar cell.

In the nature of photovoltaic (PV) technology, the higher efficiencies will ultimately cause in lower costs. Thus, PV modules using high-efficiency solar cell will have the same or lower price than conventional ones, after mass volume production and competition. The heterojunction with intrinsic thin film (HIT) and interdigital back contact (IBC) solar cell in particular are high high-efficiency 
silicon-based solar cells, with efficiencies larger than $26 \%$. In the HIT solar cell structure, thin intrinsic amorphous silicon (a-Si) layers are used to passivate the silicon surface, which are a buffer layer at the top and bottom surfaces of single crystalline n-type silicon wafer. IBC is a back contact energy conversion device, instead of front contact energy conversion. Thus, without any metal ribbons shading on top surface, an IBC solar cell can receive the entire front of the cell to absorb sunlight, thus converting more photons to energy. Although the added value per cell makes it desirable, the production process of HIT and IBC solar cell is slightly complex, as compared to conventional Al-BSF solar cell.

Table 1. Conversion efficiencies of various types of solar cells.

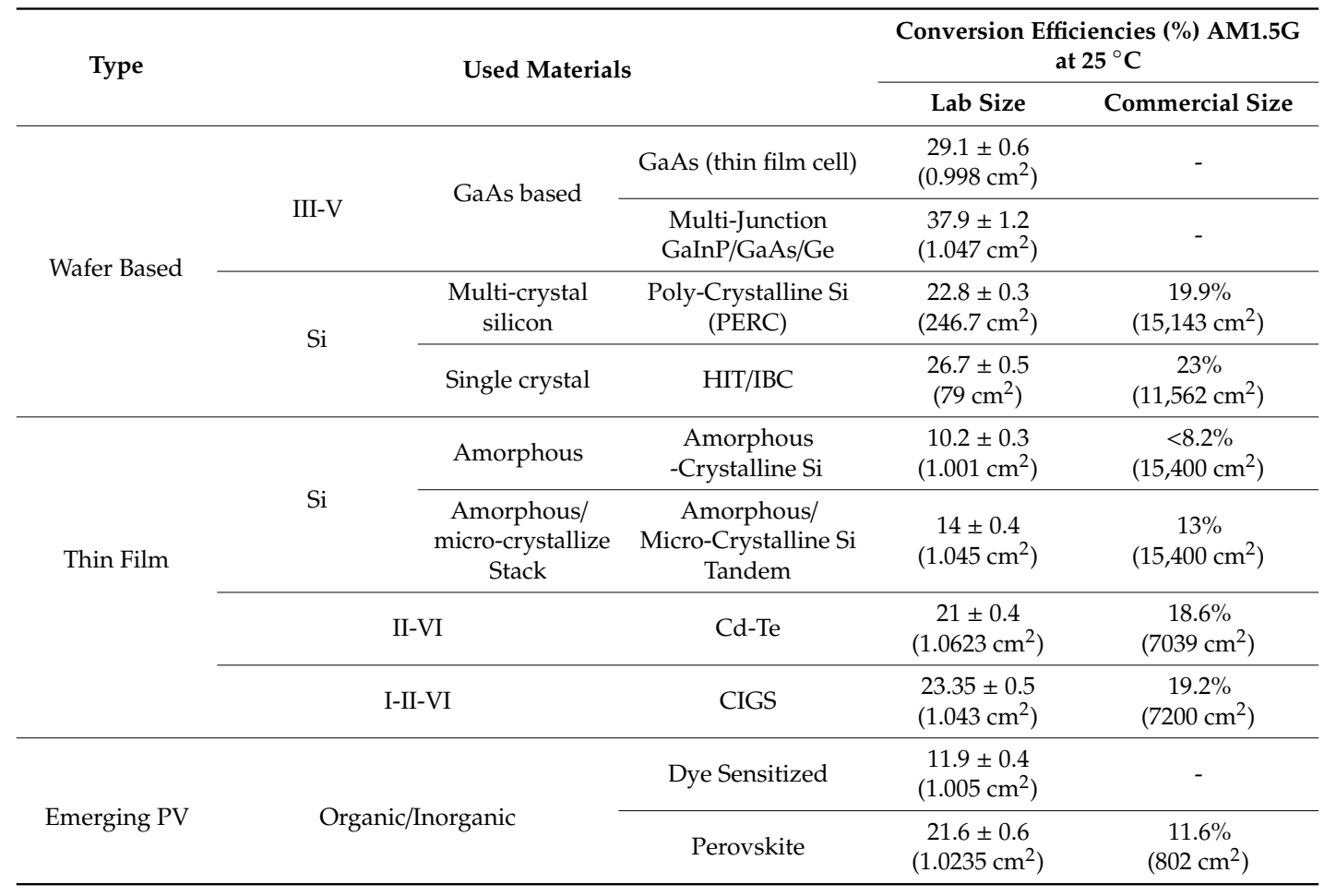

In addition, tunneling oxide passivated contact (TOPCon) technology can also achieve high efficiency, due to its excellent passivation ability and high driving effect of field effect charge. The TOPCon solar cell is currently attracting interest from many research institutions and manufacturers $[7,8]$. In recent years, the TOPCon solar cell technology has attracted widespread attention in the domestic and international units. Several research units have applied and arranged related patent applications [9]. Surface passivation by the tunneling oxide layer and the selective contact to achieve a very low recombination rate through heavily doping polysilicon film are the main feature of the TOPCon solar cell. With comparison of other potential high-efficiency silicon-based solar cells (such as HIT/ IBC), the advantage of the TOPCon solar cell is that it can be upgraded from the existing PERC technology. Therefore, in theory, less capital investment can be used to improve existing production lines for PERC solar cell. The TOPCon solar cell can achieve a good increment of a $1 \%$ increase in the absolute value of solar cell efficiency. Moreover, depending on the application field, sometimes TOPcon is called "Carrier-selective contacts". Not only in the photovoltaic field, but also PV-assisted $\mathrm{H}_{2}$ production or solar-fuel field, which is an emerging field of TOPcon device application. The information disclosed in the patent application is valuable for the identification of trends in specific technical fields $[10,11]$. In addition, the quality of the patent application, as well as the patent layout strategy, of the TOPCon solar cell, will also affect the application of subsequent entrants. Therefore, it is worth studying the development trend of the TOPCon solar cell, according to the information provided by the patent literature. However, the development trend of TOPCon solar cell technology is 
not found by using the latest patent documents to discuss. Due to the high potential of its industrial applications, studying the patent application of this field is very necessary. The aim of this research is to study the special aspects in the existing patent application of TOPCon solar cell technology:

1. What countries/companies/applicants filing the patent in the past years are analyzing the patent management charts?

2. What technical trends of the current application can be identified by analyzing the IPC classification and technology cluster?

3. What future research directions can be indicated by analyzing the technical-function matrix to identify the distribution of technology-intensive areas and technology blank areas?

Based on the patent analysis, the involved companies can decide the directions of research and development, and also avoid infringing the patents of their competitors.

Therefore, this study intends to present a patent analysis for the TOPCon solar cells. The remainder of this paper is organized as follows: the first section illustrates the research background and motivation of this study regarding to the PV technology; the second section discusses the related literature review of the used technologies to be declared, including the significance of TOPCon solar cells; the third section shows the research contents, and the patent search arrangement; the fourth section outlines the analyzed results, including the patent management analysis and the technology-function matrix analysis. Finally, the discoveries of the entire research, and recommendations for patent layout strategy, are summarized.

\section{Literature Review}

\subsection{Review of TOPCon Solar Cell Technology}

\subsubsection{Development History}

The crystalline silicon wafer solar cell has been well studied for the last few decades. When the metal is in direct contact with the silicon wafer, there is a large density of electrons in the vicinity of the junction, resulting in a large recombination loss of the solar cell. In the past, there were two ways to minimize the carrier recombination of the metal directly in contact with the silicon wafer: (1) by reducing the contact area and using local lightly doping; and (2) by using a thin film of the passivated silicon surface, to separate the metal from the silicon wafer [12-14]. The first example of the above methods is a Passivated Emitter and Rear Cell (PERC), which is derived from a conventional $\mathrm{PN}$ junction structure, using local doping only in the emitter contact area. Nowadays, its current efficiency can reach as high as $22.8 \%$. The second example of the above methods is Heterojunction with Intrinsic Thin-layer (HIT) solar cell, developed by Panasonic company, the efficiency of which is currently reported at $26.7 \%[4,5]$.

The TOPCon solar cell can also be seen to be derived from the traditional PN junction structure, combined the advantages of the above two methods. In recent years, due to excellent passivation, the TOPCon solar cell has become the mainstream of research in the world. At present, the n-type solar cell with full-region charge carrier selective back contact is a double-sided contact solar cell proposed by the Fraunhofer Institute of Germany, with a highest efficiency record of $26.7 \%$ [4,5]. This high efficiency is due to the fact that the n-type silicon has a higher impurity tolerance advantage, and the surface defects are well passivated. Many reports have demonstrated that substrate resistance between 1 and $10 \Omega \mathrm{cm}$ used for the TOPCon solar cell can achieve efficiencies greater than $25 \%$ [14]. In order to increase the efficiency of solar cell and preserve a process that can continue to be optimized, the charge carrier selective contact is used in the proposed TOPCon solar cell.

Compared with the conventional silicon based solar cell, the TOPCon solar cell achieves the following functions $[15,16]$ :

1. The ultra-thin oxide layer fills the defects that occur at the single crystal surface, thus increasing the conversion efficiency. 
2. The ultra-thin oxide layer allows rapid electron/hole migration, depending on the substrate's conductivity type.

3. As a result of the high conductivity of the highly doping polysilicon, the junction resistance can be reduced and the output current can be increased.

\subsubsection{Structure of TOPCon Solar Cell}

Figure 3 is a basic structure of the TOPCon solar cell, mainly formed by a PN junction on an n-type substrate [6,14]. The cell is passivated by a $\mathrm{Al}_{2} \mathrm{O}_{3}$ thin film on the $\mathrm{P}$ type surface, and is composed of an ultra-thin $2 \mathrm{~nm} \mathrm{SiO} 2$ tunneling layer and a heavily doping polysilicon layer on the $\mathrm{N}$ type surface [17]. The main feature of the TOPCon solar cell is surface passivation by the tunneling oxide layer, and the selective contact to achieve a very low recombination rate through heavily doping polysilicon film. The tunneling $\mathrm{SiO}_{2}$ layer needs to be thin enough to allow most of the carriers to tunnel, but at the same time, its field effect can prevent the minority carriers from transmitting [18]. The passivation quality of the heavily doping polysilicon film is varied by adjusting the hydrogen dilution rate by physical vapor deposition (PVD), such as sputtering or atomic layer deposition (ALD), or chemical vapor deposition (CVD), such as low pressure chemical vapor deposition (LPCVD), or plasma enhanced chemical vapor deposition (PECVD). The heavily doping polysilicon film exhibits good passivation quality, due to the large amount of hydrogen atoms in the polysilicon film [19].

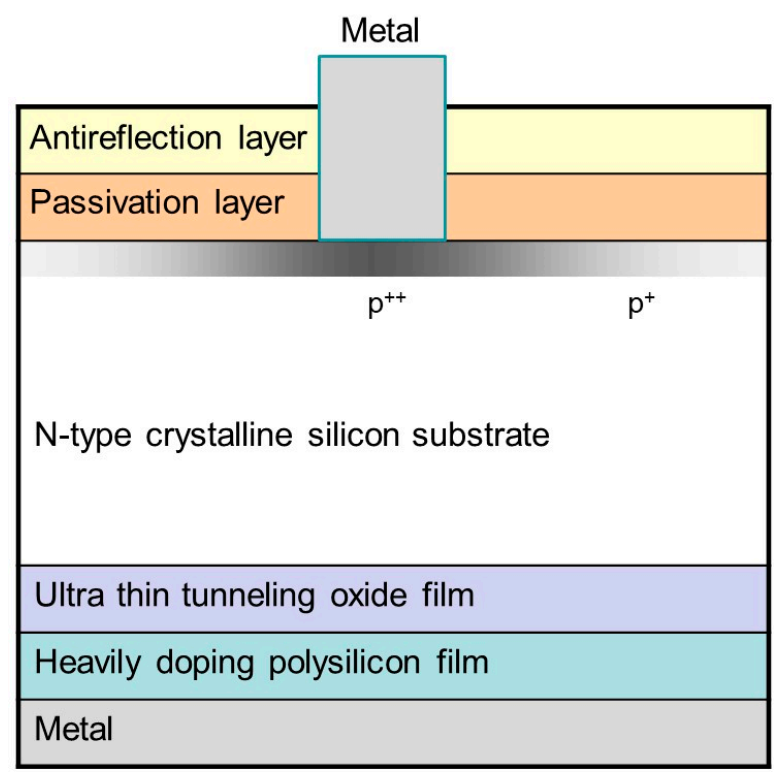

Figure 3. Basic structure of the tunneling oxide passivated contact (TOPCon) solar cell.

\subsubsection{Process of TOPCon Solar Cell}

\subsubsection{Ultra-Thin Oxide Layer}

Effective techniques for forming ultra-thin oxide layers of the TOPCon solar cell from around 1.4 to $1.5 \mathrm{~nm}$ include: wet chemical dipping, thermal oxidation, and $\mathrm{UV} / \mathrm{O}_{3}$ processing. Among them, the easiest way to form the thin oxide layer is wet chemical dipping in the acidic solution at a temperature above $90^{\circ} \mathrm{C}$. The thermal oxidation process can be further divided into dry oxygen oxidation and wet oxygen oxidation, according to the used oxidizing atmosphere. Dry oxygen oxidation uses dry, pure oxygen as an oxidizing atmosphere, and oxygen reacts directly with hydrazine gas at high temperatures, to form the oxide film. The wet oxygen is a high-purity water vapor as an oxidizing atmosphere, and the oxide and water molecules on the surface react to form the oxide film. In general, the oxidation rate of wet oxygen is larger than that of dry oxygen oxidation $[15,17]$. 


\subsubsection{Doped Polysilicon Layer}

The heavily doping polysilicon film is formed by 1) depositing a silicon film by LPCVD, combining with extra ion doping, or 2) directly depositing a doping silicon film layer by PECVD.

\subsection{Review of Patent Analysis}

\subsubsection{Patent}

Patent is the right granted to research products or technical personnel, and is the most commonly used protection method for the development of science and technology. The purpose of the establishment of the patent is to allow the owner of the invention to prevent others from making, using, or selling its invention within a certain period, so the rights of the inventor can be protected. The number of patents shows the progression of scientific and technological knowledge, and also reveals the development of technology [20-25]. Patent data is often used for technology evaluation and prediction. In current corporate competition, intellectual property is one of the most powerful tools used by major R\&D companies worldwide to contain competitors. The more detailed the patent information data in the industry, the more exactly the manufacturer can formulate the company's business strategy, R\&D strategy and patent strategy. Therefore, conducting thorough patent analysis and planning at the beginning of $R \& D$ is a topic that prospective business leaders must pay special attention to [26].

\subsubsection{Patent Analysis}

Patent analysis is an essential way to systematically organize patent information. By presenting patent data on a visualization chart, complex patent-related information becomes clear, so readers can easily understand the development of patent technology in the field, as well as other information. With the use of patent analysis, researchers can conduct research, development, and investment management [27]. Patent analysis is an operative tool for technology research planning and intellectual property management; thus, patent analysis is the basis for technology competition analysis and technology trend analysis [28].

\section{Methodology}

\subsection{Patent Search Strategy}

In this study, the MTrends Patent Search and Analysis System software was used. The search area includes the USA, the EU, and the World Intellectual Property Organization (WIPO). The search period is from 1976 until 2019/07/31. When analyzing, the patents with the same application number are merged into one case for analysis. The search strategy is to set search keywords based on the important technical features of TOPCon solar cell in the corresponding fields, as shown in Table 2. A few less relevant patents were eliminated, with a primary interpretation of the content of the searched patents. After deleting some patents that did not fit the subject, the search result has 173 cases with total of 220 patents, of which 53 were approved and 167 were published.

Table 2. Search strategy of patent analysis for the TOPCon solar cell.

\begin{tabular}{ll}
\hline \multicolumn{1}{c}{ Keywords } & \multicolumn{1}{c}{ Fields } \\
\hline solar cell & \\
photovoltaic & abstract \\
tunnel & title \\
passivat & claims \\
oxide & International Patent Classification (IPC) \\
silicon & \\
\hline$*$ Attached to the end of the word means all the letters following this word.
\end{tabular}

* Attached to the end of the word means all the letters following this word. 


\subsection{Patent Management Charts}

Typically, the patent analysis includes two analyzed types: the patent management analysis and the technology-function matrix analysis.

The patent management charts can show the development trends of the research topic in different ways, such as "number of patents", "country", "company", "International Patent Classification (IPC)", "technology life cycle" etc. The important patent management charts are explained as follows.

1. Analysis of the number of patents over the years: this analysis is used to explore the number of patent applications and publication in each year; thus, to observe the patent development trend of TOPCon solar cell technology over time. The patent application date refers to the date when the patent was filed, and the patent publication date refers to the date on which the patent application is early published.

2. Analysis of technology life cycle: this analysis has four distinct stages: research and development, ascent, maturity, and decline. This analysis is used to observe the technological development phase of TOPCon solar cells.

3. Analysis of country: this analysis is used to explore the development of TOPCon solar cell technology in various countries, and to understand the distribution of leading countries in the field of TOPCon solar cell technology.

4. Analysis of patent assignee: this analysis is used to explore the technological development and the patent portfolio status of leading companies in the field of TOPCon solar cell technology, and to learn more about the R\&D direction of the competitors.

5. Analysis of IPC classification: typically, it is not easy for patent analysts to evaluate and screen a large number of patent search results. Therefore, this analysis is used to explore the IPC, to help the patent analysts, to screen and classify the patents more precisely.

The technical-function matrix analysis is another analysis technique, often used in patent analysis. For the patent information of the analysis subject, it is read one by one to mark the type and effect of the technology, and then statistics are performed. By analyzing the technology-function matrix, the distribution of technology-intensive areas (technical minefields) and technology blank areas (zones to be developed) can be observed, to help companies avoid infringing the patents of others in technology-intensive areas, and design patent avoidance earlier. New research and development directions can be found in technical blanks.

\section{Analysis Results}

\subsection{Patent Management Charts}

\subsubsection{Analysis of Number of Patent over the Years}

Figure 4 shows the trend of number of patents of the TOPCon solar cell over the years. TOPCon solar cell related technologies have patent outputs since 1977. According to the filed date, there have been obvious output since 2006, with approximately more than five patent applications each year, and a relatively large number of patents output (more than 20 patent applications) from 2014 to 2016. According to the date of patent publication, there are as many as 20 or more patent publications each year from 2016 to 2018, indicating that this technology is still at its peak. At the data of July 2019, the patent information for 2019 is incomplete. 


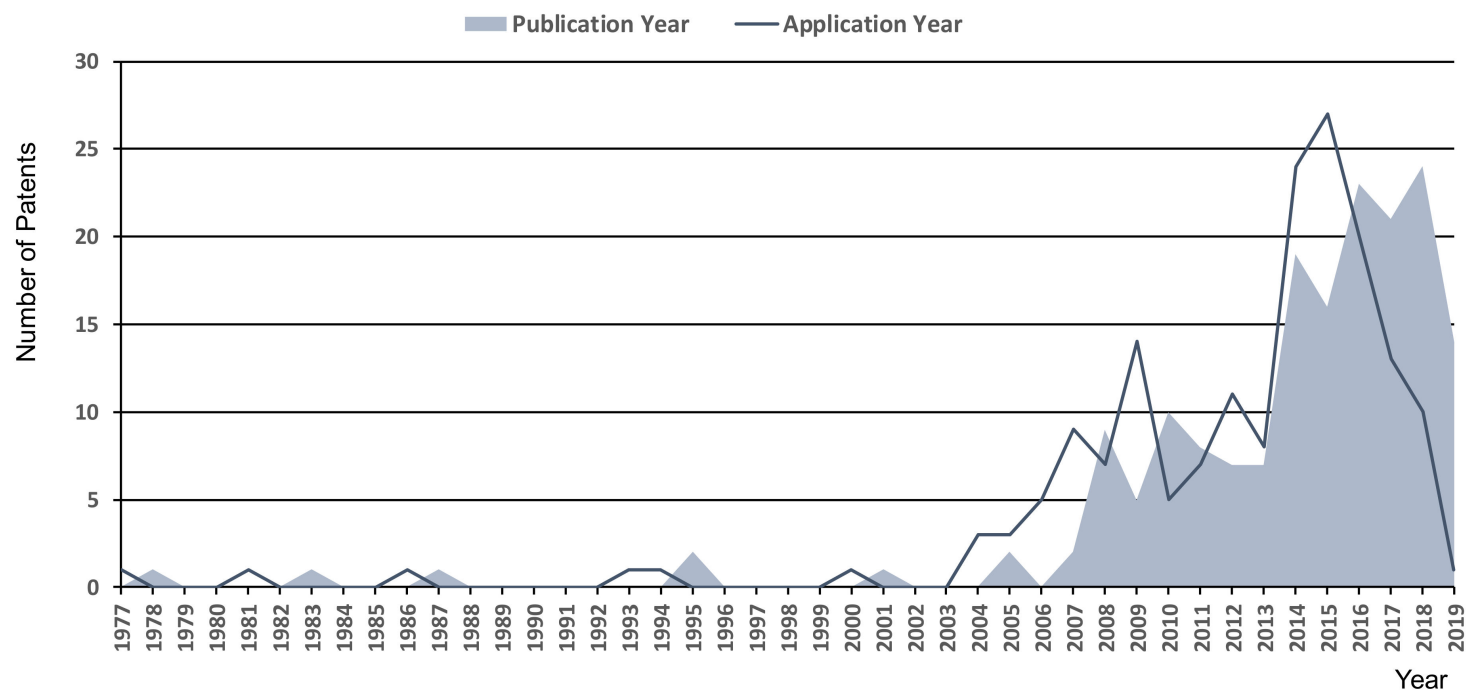

Figure 4. Trend of number of patents over the years.

\subsubsection{Analysis of Technology Life Cycle}

Figure 5 presents the trend of technology life cycle of the TOPCon solar cell. TOPCon solar cell related technologies have been in the research and development phase since 1977, and have entered into the ascent phase since 2010. It reached the inflection point in the technology history and entered into the maturity stage in 2019. However, we learn from the relevant industry news that this technology has not yet been fully mass-produced.

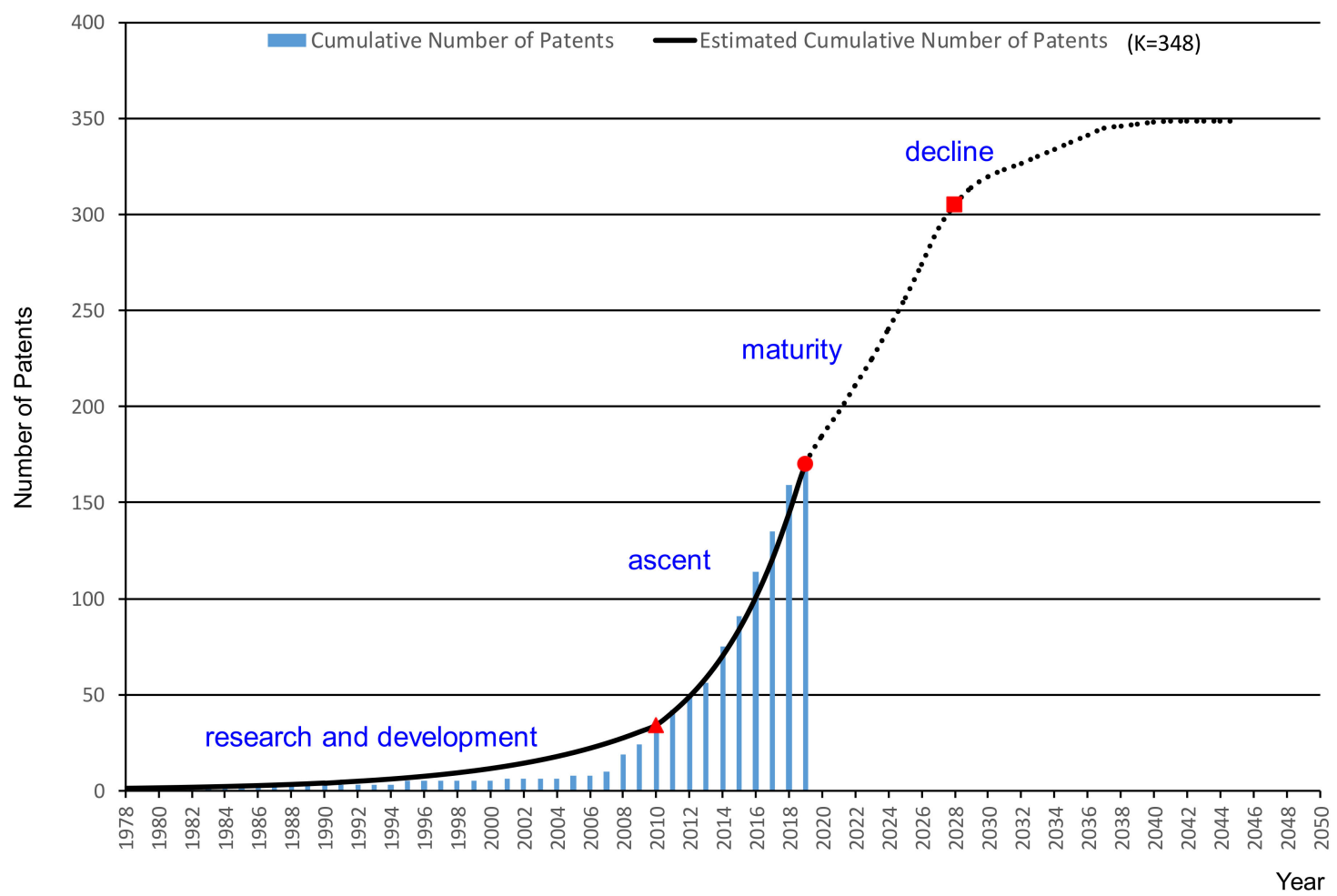

Figure 5. Trend of technology life cycle of the TOPCon solar cell.

\subsubsection{Analysis of Country}

Figure 6 illustrates the distribution of major countries of the TOPCon solar cell. The country with the largest number of patents for TOPCon solar cell is the United States, with a total of 103 patents, 
accounting for up to $60 \%$. The second is South Korea, with a total of 37 patents, accounting for $21 \%$. The third is the Netherlands, with a total of 11 patents.

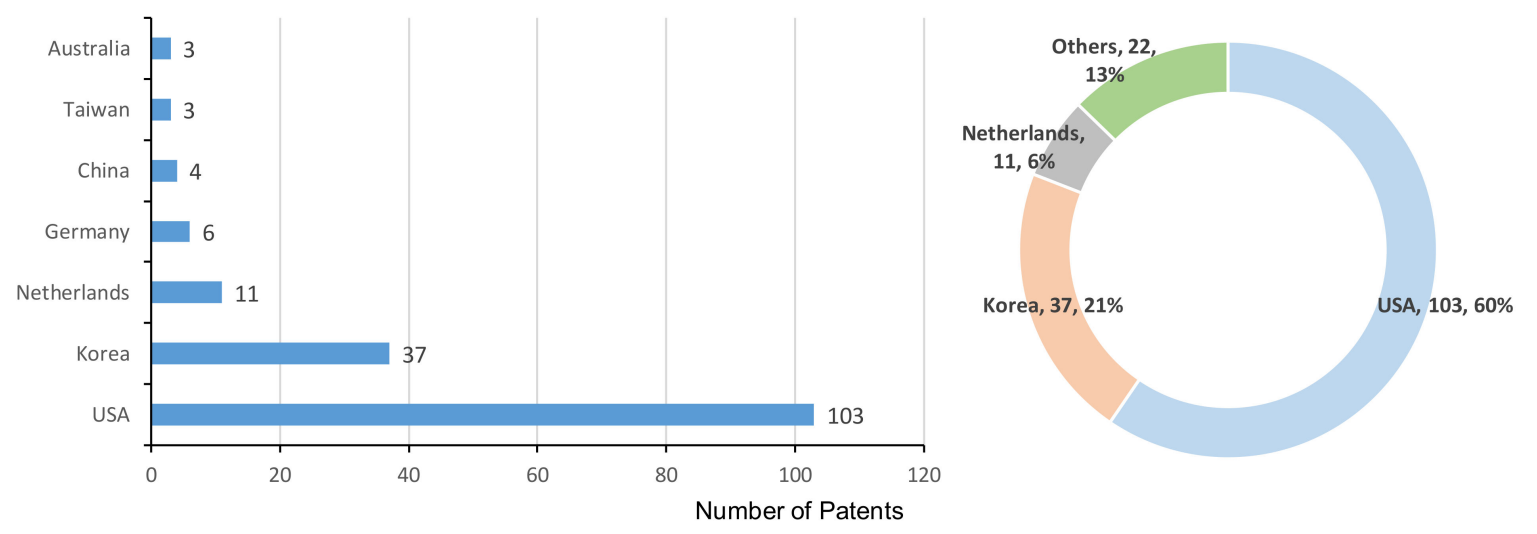

Figure 6. Distribution of major countries of the TOPCon solar cell.

\subsubsection{Analysis of Patent Assignee}

Figure 7 indicates the distribution of major patent assignees of the TOPCon solar cell. The company with the largest number of patents for TOPCon solar cell is LG Electronics, with a total of 35 patents. This is followed by SunPower, SolarCity (which was acquired by Tesla in 2016) and Applied Materials, with 24,13, and 8 patents, respectively. Compared with the distribution of major countries shown in Figure 6, the United States has the largest number of patents, but the assignees are scattered. South Korea has fewer patents than the US, but patents are concentrated in LG Electronics Inc. Chinese assignees have few patents in the USA, EU, and WIPO. However, Chinese manufacturers have invested in TOPCon solar cell. Therefore, it is estimated that the portfolio of Chinese manufacturers is still mainly domestic.

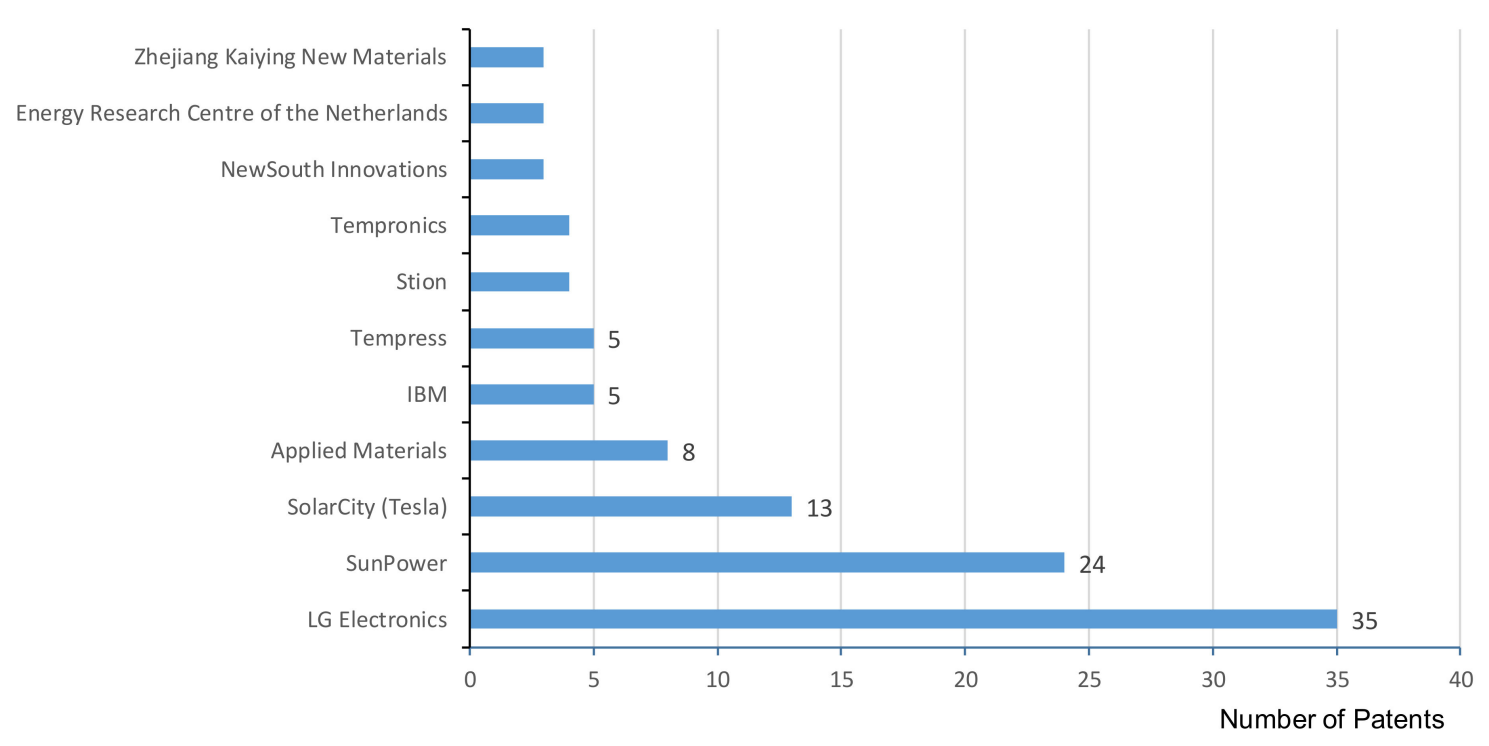

Figure 7. Distribution of major patent assignees of the TOPCon solar cell.

Table 3 shows the R\&D intensity comparison of major patent assignees. According to the number of patents, others/self-citations, and inventors, and the average age of patents, it is observed that LG Electronics has the relative strongest R\&D capabilities, followed by SunPower, SolarCity (Tesla), Applied Materials, IBM, and Tempress. According to Table 3, the number of others/self-citations of LG Electronics are both 0 , so it can be seen that the patents of LG Electronics are not parent applications, and 
there is no continuous trend toward the relevant technology. On the contrary, the patents of SunPower are mostly parent applications, and there is continuous trend toward the relevant technology.

Table 3. R\&D intensity comparison of major patent assignees.

\begin{tabular}{lccccccc}
\hline Patent Assignee & $\begin{array}{c}\text { Number } \\
\text { of Patents }\end{array}$ & $\begin{array}{c}\text { Number of } \\
\text { Other-Citations }\end{array}$ & $\begin{array}{c}\text { Number of } \\
\text { Self-Citations }\end{array}$ & $\begin{array}{c}\text { Number } \\
\text { of } \\
\text { Inventors }\end{array}$ & $\begin{array}{c}\text { Average } \\
\text { Age of } \\
\text { Patents }\end{array}$ & $\begin{array}{c}\text { Activity } \\
\text { Year of } \\
\text { Patent }\end{array}$ & $\begin{array}{c}\text { Relative } \\
\text { R\&D } \\
\text { Capability }\end{array}$ \\
\hline LG Electronics & 35 & 0 & 0 & 66 & 2 & 6 & $100 \%$ \\
SunPower & 24 & 7 & 3 & 32 & 5 & 10 & $69 \%$ \\
SolarCity (Tesla) & 13 & 2 & 3 & 7 & 4 & 7 & $35 \%$ \\
Applied Materials & 8 & 0 & 0 & 12 & 4 & 3 & $16 \%$ \\
IBM & 5 & 0 & 0 & 8 & 1 & 2 \\
Tempress & 5 & 0 & 0 & &
\end{tabular}

Figure 8 displays the timeline of technology development of major patent assignees. From the timeline of the technology development, the patent output time of the top six patent assignees is almost all after 2010. It also validates from the technology life cycle that TOPCon solar cell related technologies have had related patent output since 1977, and have entered into the ascent phase since 2010. The following conclusions can be deduced from Figure 8:

1. SunPower is the earliest patent assignee among the top six companies. It is estimated that its early patents might be the parent applications of the initial structure of the TOPCon solar cell.

2. Applied Materials is an equipment manufacturer. Its patent outputs are concentrated between 2009 and 2013. It is estimated that Applied Materials invested in solar cell process in order to develop equipment. Once the equipment is developed, there is no need for Applied Materials to apply for patents.

3. LG Electronics is the follower among the top six companies. Its patent outputs are heavily concentrated after 2014. LG Electronics is the important company to watch in the near future.

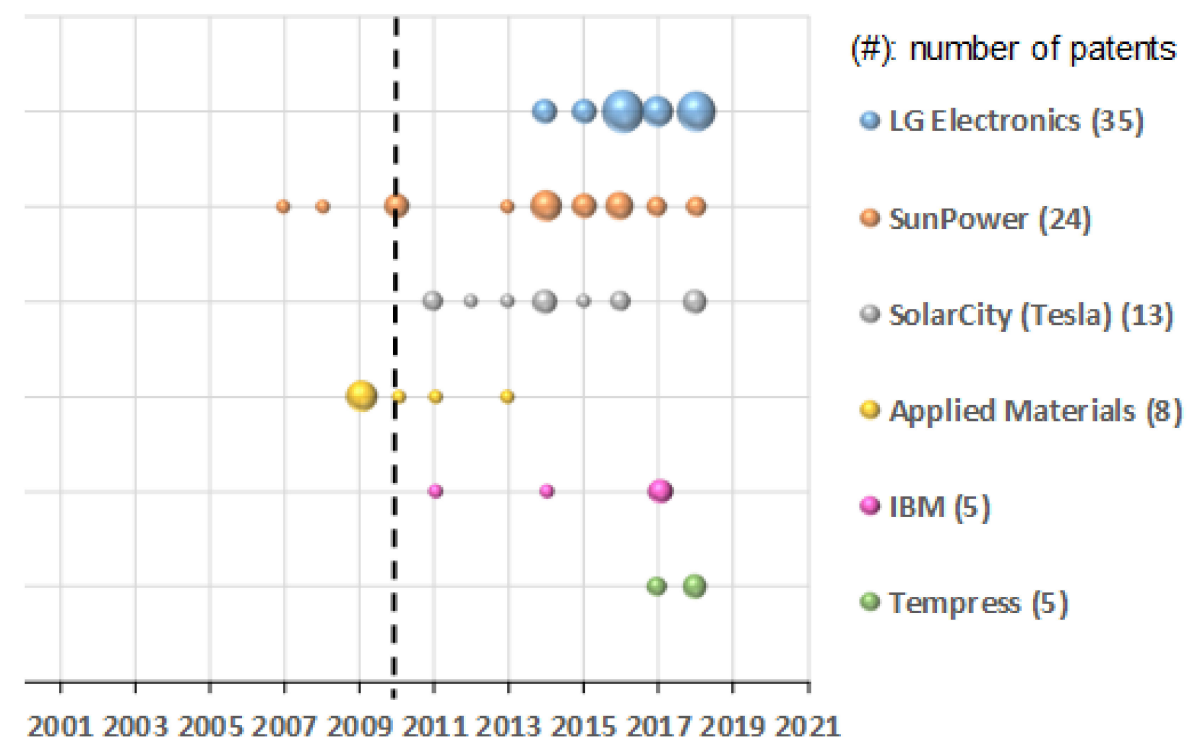

Figure 8. Timeline of technology development of major patent assignees.

\subsubsection{Analysis of IPC Classification}

Table 4 presents the distribution of major IPC. The technical fields of TOPCon solar cell mostly belong to the IPC subdivision H01L 31, with a total of 145 patents, accounting for about 83.8\%. Subdivided to the next level, the IPC subdivision with the largest number of patents for TOPCon solar cell is H01L 31/0224, with a total of 32 patents, accounting for about $18.5 \%$, and this is followed by H01L 31/00 and H01L 31/18, with $11.6 \%$ and 7.5\%, respectively. 
Table 4. Distribution of major International Patent Classification (IPC).

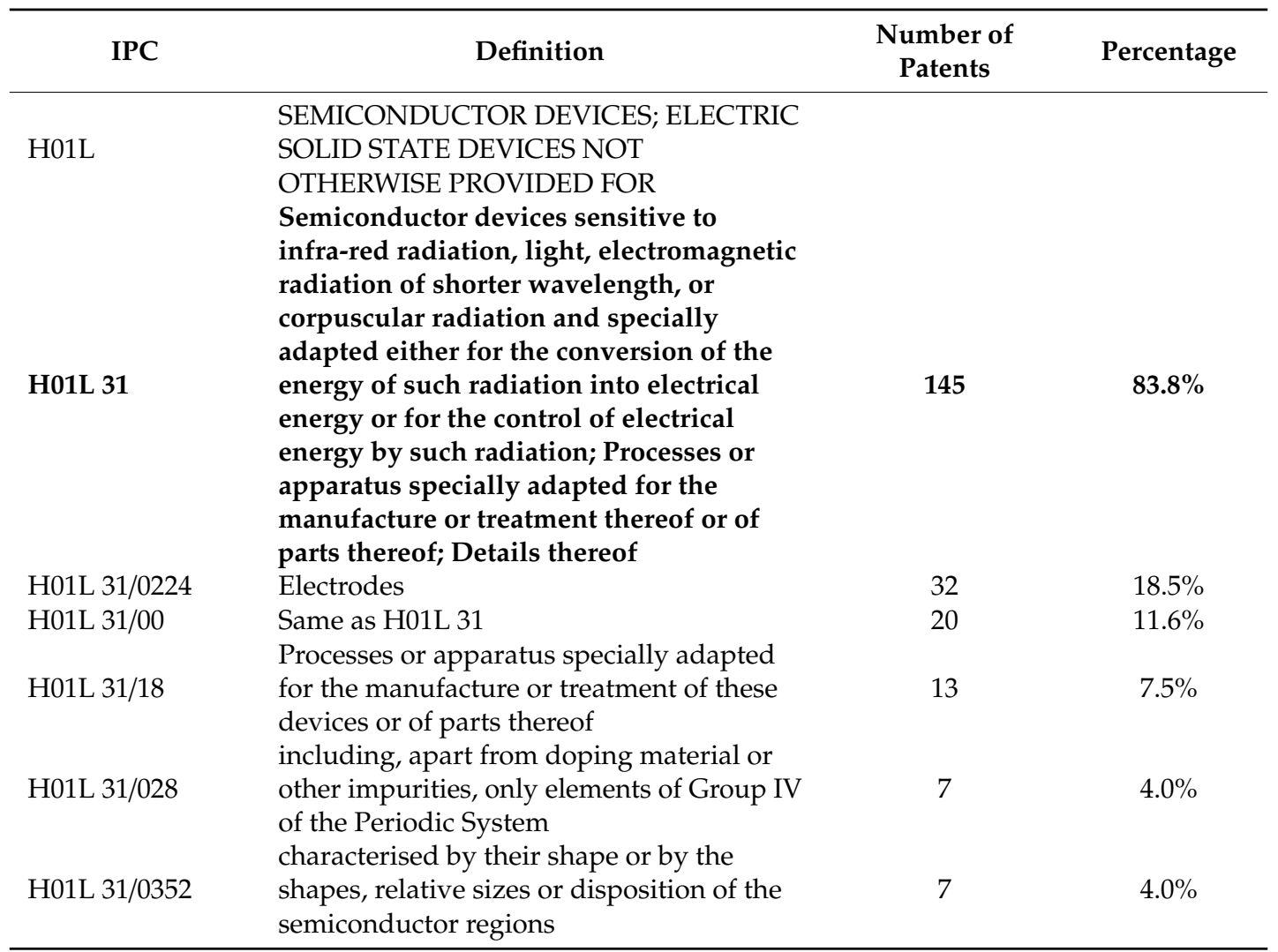

Figure 9 shows the IPC distribution of major patent assignees. According to Figure 9, the patent portfolios of LG Electronics and Tempress focus on H01L 31/0024. SunPower focuses on H01L 31/028. The patent portfolios of Applied Materials and IBM focus on H01L 31/00. SolarCity (Tesla) has a more even patent portfolio, including H01L 31/0352, H01L 31/0024, H01L 31/00, and H01L 31/18.

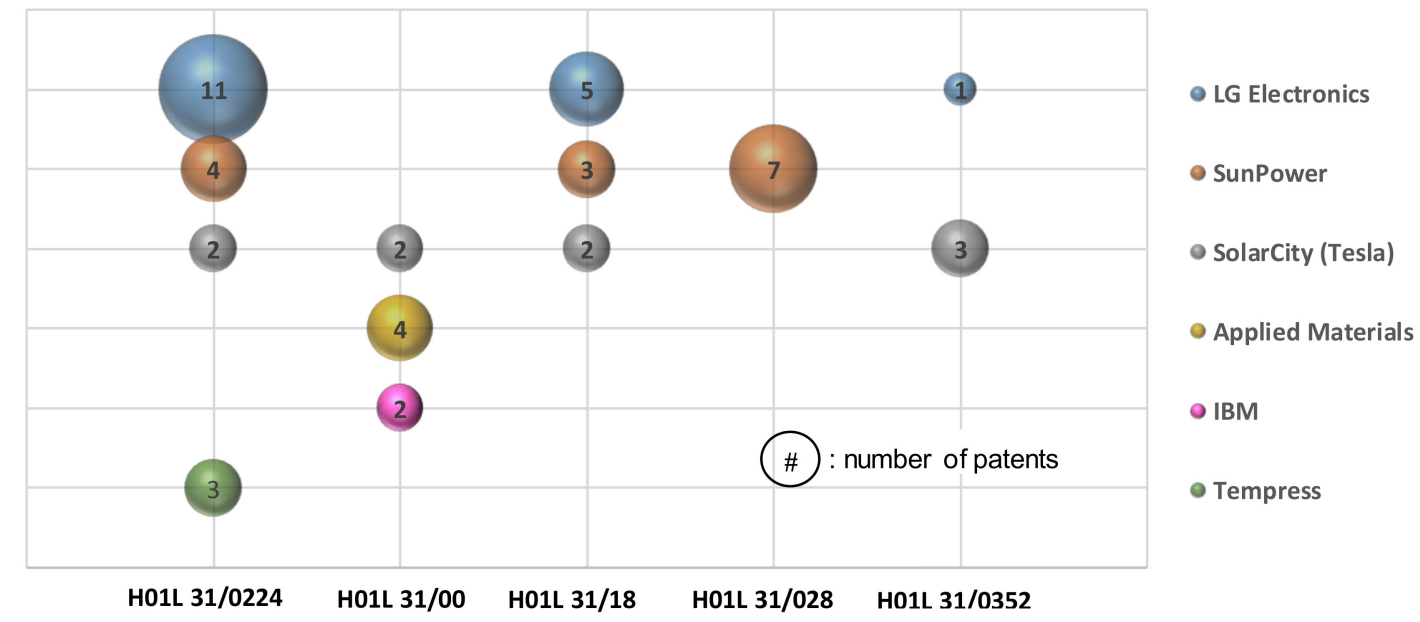

Figure 9. IPC distribution of major patent assignees.

\subsection{Patent Technology-Function Matrix}

\subsubsection{Classification of Technology and Function}

The related technologies of TOPCon solar cells can be divided into two types of first-order technologies: components and processes. The cell structure and key processes/equipment (as shown 
in Figure 3) can be further analyzed, and the second-order technologies can be further subdivided, as shown in Table 5. The function of TOPCon solar cells can be divided into three types of first-order effects, such as microstructure, photoelectric characteristics, and others, and can be further subdivided into second-order effects, as shown in Table 6.

Table 5. Technology classification of TOPCon solar cell.

\begin{tabular}{|c|c|c|}
\hline First-Order Technology & \multicolumn{2}{|c|}{ Second-Order Technology } \\
\hline Devices & \multicolumn{2}{|c|}{$\begin{array}{c}\text { Substrate } \\
\text { Tunneling oxide } \\
\text { Poly-Si } \\
\text { Passivation layer } \\
\text { Electrode } \\
\text { Others }\end{array}$} \\
\hline \multirow{4}{*}{ Process } & \multicolumn{2}{|c|}{ Diffusion (doping) } \\
\hline & Oxide formation & $\begin{array}{l}\text { Dry } \\
\text { Wet } \\
\text { CVD }\end{array}$ \\
\hline & Passivation & $\begin{array}{l}\text { PVD } \\
\text { CVD }\end{array}$ \\
\hline & Poly-Si & $\begin{array}{l}\text { LPCVD } \\
\text { PECVD }\end{array}$ \\
\hline
\end{tabular}

Table 6. Function classification of TOPCon solar cell.

\begin{tabular}{cc}
\hline First-Order Function & Second-Order Function \\
\hline Microstructure & Film uniformity \\
& Defect \\
& Carrier lifetime \\
\hline Photoelectric characteristics & Short circuit current (Jsc) \\
& Open circuit voltage (Voc) \\
& Filling factor (FF) \\
Others & Efficiency \\
& Cost \\
& Reliability \\
\hline
\end{tabular}

\subsubsection{Technical-Function Matrix Analysis}

Figure 10 is the patent technology-function matrix of TOPCon solar cell related technologies. As shown in Figure 10, the first development focus of the device-related technologies is tunneling oxide. There is a total of 68 patents, indicating that tunneling oxide is the most critical technology core of TOPCon solar cells, which can be used to improve the conversion efficiency. The second development focus of the device-related technologies is polycrystalline silicon, which has 21 patents, indicating the necessity of polycrystalline silicon in TOPCon solar cells. 


\begin{tabular}{|c|c|c|c|c|c|c|c|c|c|c|c|c|c|c|c|c|}
\hline \multirow{3}{*}{\multicolumn{2}{|c|}{ Function }} & \multicolumn{6}{|c|}{$\begin{array}{l}\text { Devices T1 } \\
\end{array}$} & \multicolumn{8}{|c|}{ Process T2 } & \multirow{3}{*}{ Total } \\
\hline & & \multirow{2}{*}{\begin{tabular}{|c|} 
Sub- \\
strate \\
T11
\end{tabular}} & \multirow{2}{*}{$\begin{array}{c}\text { Tunneling } \\
\text { oxide } \\
\text { T12 }\end{array}$} & \multirow{2}{*}{$\begin{array}{c}\text { Poly-Si } \\
\text { T13 }\end{array}$} & \multirow{2}{*}{$\begin{array}{c}\text { Passivation } \\
\text { layer } \\
\text { T14 }\end{array}$} & \multirow{2}{*}{$\begin{array}{c}\text { Elec- } \\
\text { trode } \\
\text { T15 }\end{array}$} & \multirow{2}{*}{$\begin{array}{c}\text { Others } \\
\text { T16 }\end{array}$} & \multirow{2}{*}{$\begin{array}{c}\text { Diffusion } \\
\text { (doping) } \\
\text { T21 }\end{array}$} & \multicolumn{3}{|c|}{ Oxide formation } & \multicolumn{2}{|c|}{ Passivation } & \multicolumn{2}{|c|}{ Poly-Si } & \\
\hline & & & & & & & & & $\begin{array}{l}\text { Dry } \\
T 22\end{array}$ & \begin{tabular}{|l|} 
Wet \\
T23
\end{tabular} & $\begin{array}{l}\text { CVD } \\
\text { T24 }\end{array}$ & $\begin{array}{l}\text { PVD } \\
\text { T25 }\end{array}$ & $\begin{array}{l}\text { CVD } \\
\text { T26 }\end{array}$ & $\begin{array}{c}\text { LPCVD } \\
\text { T27 }\end{array}$ & $\begin{array}{c}\text { PECVD } \\
\text { T28 }\end{array}$ & \\
\hline \multirow{3}{*}{$\begin{array}{l}\text { Micro- } \\
\text { structure } \\
\text { F1 }\end{array}$} & $\begin{array}{c}\begin{array}{c}\text { Film } \\
\text { uni- } \\
\text { formity } \\
\text { F11 }\end{array} \\
\end{array}$ & & & & & & & & & & & & & 1 & 1 & 2 \\
\hline & $\begin{array}{c}\text { Defect } \\
\text { F12 } \\
\end{array}$ & & 7 & 1 & 4 & 1 & & & & & & & & & & 13 \\
\hline & $\begin{array}{c}\text { Carrier } \\
\text { lifetime } \\
\text { F13 } \\
\end{array}$ & & 1 & 1 & 4 & & & & & & 2 & & & & & 8 \\
\hline \multirow{4}{*}{ 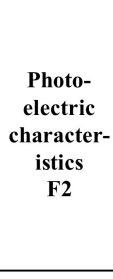 } & $\begin{array}{l}\text { Jsc } \\
\text { F21 } \\
\end{array}$ & & 5 & 1 & 1 & 1 & & 1 & & & 2 & & & & 2 & 13 \\
\hline & $\begin{array}{l}\text { Voc } \\
\text { F22 }\end{array}$ & & 10 & 2 & & 1 & & & & & & & 1 & & 1 & 15 \\
\hline & $\begin{array}{c}\mathbf{F F} \\
\mathbf{F} 23 \\
\end{array}$ & & 1 & 1 & 2 & & 1 & & 1 & & & & & & & 6 \\
\hline & $\begin{array}{c}\text { Effi- } \\
\text { ciency } \\
\text { F24 } \\
\end{array}$ & 3 & 30 & 9 & 4 & 1 & 1 & & 2 & 2 & 4 & & & 3 & & 59 \\
\hline \multirow{2}{*}{$\begin{array}{c}\text { Others } \\
\text { F3 }\end{array}$} & $\begin{array}{l}\text { Cost } \\
\text { F31 }\end{array}$ & & 5 & 4 & 3 & 5 & 4 & & & 1 & 2 & 1 & 2 & 1 & 1 & 29 \\
\hline & $\begin{array}{c}\text { Relia- } \\
\text { bility } \\
\text { F32 } \\
\end{array}$ & & 9 & 2 & 2 & 4 & 4 & & & 2 & 1 & & & 3 & 1 & 28 \\
\hline \multicolumn{2}{|c|}{ Total } & 3 & 68 & 21 & 20 & 13 & 10 & 1 & 3 & 5 & 11 & 1 & 3 & 8 & 6 & 173 \\
\hline
\end{tabular}

Figure 10. Technology-function matrix of TOPCon solar cells.

The first development focus of process-related technologies is the process of tunneling oxide layers, with a total of 19 patents, especially the corresponding CVD process, which holds 11 patents. The main function requirement of these key process technologies is also "improving photoelectric conversion efficiency". The second development focus of process-related technologies is the process of polysilicon film, with a total of 14 patents, including eight patents for the deposition of polysilicon films by LPCVD, combined with external ion doping, and six patents for the direct deposition of doped polysilicon film by PECVD.

From the perspective of the technology-function matrix, the future development of the TOPCon solar cell is bound to develop toward the characteristics of high conversion efficiency, low carrier loss rate, low process temperature, and good high temperature characteristics.

It is noted that in terms of the technology-function matrix, the process technology is less patented than the component technology, because the process technology is mostly a method patent, and it is more difficult to prove the infringement than the physical component. In the patent portfolio, most companies will apply for entity component structure patents, and then carry out the corresponding process invention methods for the patent portfolio of the TOPCon solar cell.

In the layout of intellectual property in technical blank areas (zones to be developed), it is recommended that the structure of the tunneling oxide layer can be paid attention to, because extremely thin and uniform film quality is required to match specific functions, such as improving uniformity and increasing the corresponding load, sub-life, or fill factor.

In terms of the process technology, it is recommended to pay attention to the polycrystalline silicon manufacturing process, including the process conditions of depositing an silicon thin film by LPCVD, combined with external ion doping; or the process conditions of directly depositing a doped silicon thin film layer by PECVD to match the specific efficiency, for example, to increase the open-circuit voltage or short-circuit current density for key related process layouts. 


\section{Conclusions}

The results of the patent analysis in the TOPCon solar cell technology have led to the following conclusions:

1. The search result has 173 cases, with total of 220 patents, of which 53 were approved and 167 were published in this study.

2. The trend of the number of patents shows that there has been obvious output since 2006, with approximately more than five patent applications each year, and a relatively large patent output (more than 20 patent applications) from 2014 to 2016.

3. The TOPCon solar cell technology reached the inflection point of technology history and entered into the maturity stage in 2019.

4. The countries with the top three number of patents are the United States, South Korea, and the Netherlands, with a total of 103,37 , and 11 patents, respectively.

5. The companies with the top three number of patents are LG Electronics, SunPower, and SolarCity (which was acquired by Tesla in 2016) with a total of 35, 24, and 13 patents, respectively.

6. LG Electronics has the relative strongest R\&D capabilities, followed by SunPower. However, SunPower is the earliest patent assignee among the top six companies, and LG Electronics is the follower among the top six companies, as its patent outputs are heavily concentrated after 2014. It is also worth noting that the patent strategy of LG Electronics is protecting their market with a series of defensive patents, which suppress other companies' patent activities.

7. The IPC subdivisions with the top three number of patents are H01L 31/0224, H01L 31/00, and H01L 31/18, which account for about $18.5 \%, 11.6 \%$ and $7.5 \%$, respectively.

8. Patent technology-function matrix shows the development focus of the device-related technologies are tunneling oxide, with a total of 68 patents, and polycrystalline silicon, with a total of 21 patents.

9. Patent technology-function matrix shows the main development focus among process-related technologies is the process of tunneling oxide layers, with a total of 19 patents, followed by the process of polysilicon film, with a total of 14 patents.

From the above analysis, the tunneling oxide technology is the most critical technology for TOPCon solar cells. The process conditions for high-quality ultra-thin oxide layers are also very strict. With the help of talents transferred from the semiconductor industry to the solar cell industry, the related technical problems have been solved, making is possible to achieve this process conditions for the mass production scale of solar cells.

In the next 10 to 20 years, crystalline silicon wafer solar cells should still be the mainstream of the market. Although the market is currently dominated by PERC solar cells, it is expected that, by 2025, high-efficiency n-type substrate solar cells will be the mainstream product on the market. From a cost perspective, solar cells have low added value, so manufacturers have been less willing to spend on such high-cost processes in the past.

Although HIT solar cells have expected high cost of production line equipment, HIT solar cells have fewer process steps compared to PERC. HIT solar cell manufacturers have experienced a learning curve regarding costs, and the solar cells are now are on the market. However, the real costs for TOPcon has yet to be proven in terms of large scale production. Fortunately, tunneling oxide is delicate, and can be a show-stopper in terms of stability and costs. TOPCon solar cells do not require large-scale replacement of production line equipment, and are further improved and adjusted in the original PERC or PERT process, which can reduce the cost of mass production. From the technology life cycle diagram, TOPCon solar cells entered the stage of technological growth in 2010, reached the inflection point of this technology development in 2019, and is now entering the technology maturity period. Thus, TOPCon solar cells might be competitive to the HIT solar cells in the next generation of solar cells, due to their cost to performance ratio.

Although this research has made discoveries and contributions, there are still some limitations in the research: (1) since the early disclosure of patent applications is 18 months, the number of patents in 
the past year may be incomplete; (2) because patents are territorial, certain restrictions appear when searching for related patents, due to time and geographic patent terms. Therefore, there are still errors in the evaluation of relative R\&D capabilities, but the analysis results of the overall development trend should be consistent. Due to the rapid progress of TOPCon solar cell technology, the number of patent applications and approved patents will continue to increase. Therefore, with the passage of time, the development trend in this field may still change dynamically.

Author Contributions: C.-W.T. contributed to the research concept, data collection and data analysis. T.-K.L. and P.-W.H. provided the advice on the research. C.-W.T. wrote the manuscript draft. P.-W.H. reviewed and revised the manuscript. All authors have read and agreed to the published version of the manuscript.

Funding: This research was partially funded by Bureau of Energy, Ministry of Economic Affairs of Taiwan, under grant number MOEABOE 109-D0105, and Ministry of Science and Technology of Taiwan, under grant number MOST 108-2221-E-992-095 and MOST 108-2221-E-992-084.

Acknowledgments: The authors would like to thank Min-Hang Weng for his helpful advice on various technical issues examined in this paper. Additionally, the authors would also like to thank the anonymous reviewers and the editors for their constructive suggestions which helped improve the quality of this paper.

Conflicts of Interest: The authors declare no conflict of interest.

\section{References}

1. DNV GL. Energy Transition Outlook 2018: A Global and Regional Forecast to 2050. 2018. Available online: https://eto.dnvgl.com/2018\#Energy-Transition-Outlook-2018- (accessed on 18 April 2020).

2. Jäger-Waldau, A. PV Status Report 2019; Publications Office of the European Union: Luxembourg, 2019. Available online: https:/ec.europa.eu/jrc/en/publication/eur-scientific-and-technical-research-reports/pvstatus-report-2019 (accessed on 18 April 2020).

3. DNV GL. Energy Transition Outlook 2019: A Global and Regional Forecast to 2050. 2019. Available online: https://eto.dnvgl.com/2019/index.html\#ETO2019-top (accessed on 18 April 2020).

4. Green, M.A.; Dunlop, E.D.; Hohl-Ebinger, J.; Yoshita, M.; Kopidakis, N.; Ho-Baillie, A.W.Y. Solar cell efficiency tables (Version 55). Prog. Photovolt. Res. Appl. 2020, 28, 3-15. [CrossRef]

5. Fraunhofer ISE. Photovoltaic Report. 2019. Available online: https://www.ise.fraunhofer.de/en/publications/ studies/photovoltaics-report.html (accessed on 17 March 2020).

6. Feldmann, F.; Steinhauser, B.; Arya, V.; Büchler, A.; Brand, A.A.; Kluska, S.; Hermle, M.; Glunz, S.W. Evaluation of TOPCon technology on large area solar cells. In Proceedings of the 33rd European PV Solar Energy Conference and Exhibition, Amsterdam, The Netherlands, 25-29 September 2017; pp. 465-467.

7. Steinhauser, B.; Polzin, J.-I.; Feldmann, F.; Hermle, M.; Glunz, S.W. Excellent surface passivation quality on crystalline silicon using industrial-scale direct-plasma TOPCon deposition technology. Sol. RRL 2018, 2, 1800068. [CrossRef]

8. Bae, D.; Pedersen, T.; Seger, B.; Iandolo, B.; Hansen, O.; Vesborg, P.C.K.; Chorkendorff, I. Carrier-selective p- and n-contacts for efficient and stable photocatalytic water reduction. Catal. Today 2017, 290, 59-64. [CrossRef]

9. Feldmann, F.; Bivour, M.; Reichel, C.; Hermle, M.; Glunz, S. Passivated rear contacts for high-efficiency n-type Si solar cells providing high interface passivation quality and excellent transport characteristics. Sol. Energy Mater. Sol. Cells 2014, 120, 270-274. [CrossRef]

10. Patents. World Intellectual Property Organization. Available online: www.wipo.int/patents/en (accessed on 31 March 2019).

11. Kim, G.; Bae, J. A novel approach to forecast promising technology through patent analysis. Technol. Forecast. Soc. Chang. 2017, 117, 228-237. [CrossRef]

12. Römer, U.; Peibst, R.; Ohrdes, T.; Lim, B.; Brendel, R. Recombination behavior and contact resistance of $\mathrm{n}+$ and p+ poly-crystalline Si/mono-crystalline Si junctions. Sol. Energy Mater. Sol. Cells 2014, 131, 85-91. [CrossRef]

13. Yan, D.; Cuevas, A.; Bullock, J.; Wan, Y.; Samundsett, C. Phosphorus-diffused polysilicon contacts for solar cells. Sol. Energy Mater. Sol. Cells 2015, 142, 75-82. [CrossRef] 
14. Fraunhofer ISE. TOPCon - Overcoming Fundamental Bottlenecks to a New World-Record Silicon Solar Cell. 2016. Available online: https://www.ise.fraunhofer.de/en/research-projects/topcon.html (accessed on 18 April 2020).

15. Lauinger, T.; Schmidt, J.; Aberle, A.G.; Hezel, R. Record low surface recombination velocities on $1 \Omega \mathrm{cm}$ p-silicon using remote plasma silicon nitride passivation. Appl. Phys. Lett. 1996, 68, 1232-1234. [CrossRef]

16. Grant, N.E.; Markevich, V.P.; Mullins, J.; Peaker, A.R.; Rougieux, F.; Macdonald, D.; Murphy, J.D. Permanent annihilation of thermally activated defects which limit the lifetime of float-zone silicon. Phys. Status Solidi A 2016, 213, 2844-2849. [CrossRef]

17. Lindekugel, S.; Lautenschlager, H.; Ruof, T.; Reber, S. Plasma hydrogen passivation for crystalline silicon thin-films. In Proceedings of the 23rd European Photovoltaic Solar Energy Conference, Valencia, Spain, 1-5 September 2008; pp. 2232-2235.

18. Richter, A.; Glunz, S.W.; Werner, F.; Schmidt, J.; Cuevas, A. Improved quantitative description of Auger recombination in crystalline silicon. Phys. Rev. B 2012, 86, 165202. [CrossRef]

19. Feldmann, F.; Fellmeth, T.; Steinhauser, B.; Nagel, H.; Ourinson, D.; Mack, S.; Lohmüller, E.; Polzin, J.-I.; Benick, J.; Richter, A.; et al. Large area TOPCon cells realized by a PECVD tube process. In Proceedings of the 36th European PV Solar Energy Conference and Exhibition, Marseille, France, 9-13 September 2019; pp. 304-308.

20. Joung, J.; Kim, K. Monitoring emerging technologies for technology planning using technical keyword based analysis from patent data. Technol. Forecast. Soc. Chang. 2017, 114, 281-292. [CrossRef]

21. Chen, J.H.; Jang, S.L.; Wen, S.H. Measuring technological diversification: Identifying the effects of patent scale and patent scope. Scientometrics 2010, 84, 265-275. [CrossRef]

22. Abbas, A.; Zhang, L.; Khan, S.U. A literature review on the state-of-the-art in patent analysis. World Pat. Inf. 2014, 37, 3-13. [CrossRef]

23. Karvonen, M.; Kässi, T. Patent citations as a tool for analysing the early stages of convergence. Technol. Soc. Chang. 2013, 80, 1094-1107. [CrossRef]

24. Feng, X.; Leng, F. Patent text mining and informetric-based patent technology morphological analysis: An empirical study. Technol. Anal. Strateg. Manag. 2012, 24, 467-479. [CrossRef]

25. Kim, K.H.; Han, Y.J.; Lee, S.; Cho, S.W.; Lee, C. Text mining for patent analysis to forecast emerging technologies in wireless power transfer. Sustainability 2019, 11, 6240. [CrossRef]

26. Tseng, Y.; Lin, C.; Lin, Y. Text mining techniques for patent analysis. Inf. Process. Manag. 2007, 43, $1216-1247$. [CrossRef]

27. Noh, H.; Jo, Y.; Lee, S. Keyword selection and processing strategy for applying text mining to patent analysis. Expert Syst. Appl. 2015, 42, 4348-4360. [CrossRef]

28. Choi, J.; Hwang, Y. Patent keyword network analysis for improving technology development efficiency. Technol. Forecast. Soc. Chang. 2014, 83, 170-182. [CrossRef] 